\title{
Management practices and honey characteristics of Melipona eburnea in the Peruvian Amazon
}

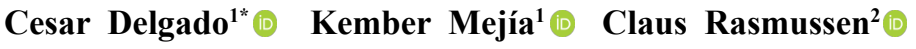

'Dirección de Investigación en Diversidad Biológica Terrestre Amazónica, Instituto de Investigaciones de la Amazonía Peruana, Iquitos, Perú. E-mail: cdelgado@iiap.gob.pe. "Corresponding author.

${ }^{2}$ Department of Agroecology, Aarhus University, Denmark.

ABSTRACT: Meliponiculture and associated honey production are activities with a great potential for general use and commercialization in the Peruvian Amazon. Lack of management techniques and limited knowledge of honey quality are two factors which may hinder the implementation of meliponiculture. The present study was conducted in three communities in the Peruvian Amazon where the production and physicochemical and microbiological characteristics of honey from Melipona eburnea were evaluated at 90 days following transfer from natural to rational hives. Honey from M. eburnea was also compared with the 90-day-old honey from Melipona grandis, Melipona illota, and Melipona titania. In addition, 180-day-old honey from M. eburnea was sampled and compared with the younger 90-day-old honey. The production of honey varied from 900 to $1400 \mathrm{~mL} /$ colony/3 months for M. eburnea. When moisture and total sugars among the different species of Melipona were compared, no significant differences were observed. Neither were there significant differences between the M. eburnea honey at 90 and 180 days of maturation. Microbiological analyses for both treatments had values $<0.3 / g$ most probable number (MPN) of coliforms and organisms of fecal origin. Stingless bee honey can therefore be harvested after 3 months, by which time its physicochemical characteristics are stable and it is microbiologically suitable for human consumption.

Key words: Meliponiculture, stingless bees, production, quality, consumption.

Práticas de manejo e características do mel de Melipona eburnea Friese na Amazônia peruana

RESUMO: A meliponicultura e a produção associada de mel é uma atividade com grande potencial de uso e comercialização na Amazônia peruana, contudo, as poucas técnicas de manejo e o pouco conhecimento da qualidade do mel oferecido limitam seu desenvolvimento. O presente estudo foi realizado em três comunidades da Amazônia peruana, onde a produção e as características físico-químicas e microbiológicas do mel de Melipona eburnea foram avaliadas 90 dias após a instalação em colmeias racionais. O mel de M. eburnea também foi comparado ao mel de 90 dias de M. grandis, M. illota e M. titania. Além disso, o mel de M. eburnea foi amostrado aos 180 dias. A produção de mel variou de 900 a $1400 \mathrm{ml} /$ colônia/três meses para M. eburnea. Quando a umidade e os açúcares totais foram comparados entre as diferentes espécies, não foram encontradas diferenças significativas. Também não foram encontradas diferenças significativas para o mel de M. eburnea aos 90 e 180 dias de maturação. As análises microbiológicas para os dois tratamentos apresentaram valores $<0,3 / \mathrm{g}$ MPN (número mais provável) de coliformes e organismos de origem fecal. O mel de abelha sem ferrão pode, portanto, ser colhido após três meses, pois mantém suas características fisico-quimicas e é microbiologicamente adequado para consumo humano.

Palavras-chave: Meliponicultura, abelhas sem ferrão, produção, qualidade, consumo.

\section{INTRODUCTION}

Meliponiculture, or the keeping of stingless bees (Hymenoptera: Apidae: Meliponini) for honey production, is an activity which has been performed since the ancient times by traditional communities in tropical and subtropical areas (CORTOPASSILAURINO et al., 2006; CAMARGO \& PEDRO,
2007; MICHENER, 2007). Traditional methods of harvesting honey involve the destruction of honey pots, surrounding cerumen (beeswax mixed with resin), brood cells, and often even the cavities hosting the colony (KERR et al., 2001; RASMUSSEN \& CASTILLO, 2003). These traditional methods may include the complete removal of resources due to the destruction of honey pots and are frequently 
followed by the death of the colony (EARDLEY \& KWAPONG, 2013; QUEZADA-EUÁN et al., 2018). In contrast, sustainable meliponiculture is an activity that fits well within the framework of diversification and sustainable use of the Amazonian territory. Here, meliponiculture could be integrated into agroforestry plantations, where it would facilitate pollination and thus increase crop production (GIANNINI et al., 2015; GARIBALDI et al., 2016). Management techniques for increasing honey production for stingless bees have been studied outside Peru with non-Peruvian species (KOFFLER et al., 2015; VENTURIERI et al., 2018; JAFFÉ et al., 2015), whereas honey quality based on physicochemical and microbiological characteristics has been studied both in Peru (RODRÍGUEZMALAVER et al., 2009) and elsewhere (LAGE et al., 2012; VIT, 2013; LEMOS et al., 2017; FERNANDES et al., 2018).

Stingless bee honey and related products, such as pollen, wax, and propolis, are harvested by communities for use in medicine, food and for religious and cultural activities (QUEZADA-EUÁN et al., 2018; ALVES \& ALVES 2011), including the Peruvian Amazon (RASMUSSEN \& CASTILLO, 2003; RODRÍGUEZ-MALAVER et al., 2009). The physicochemical composition of honey depends on the nectar and the physiology of each bee species that produce honey with its species-specific set of physical, chemical, biochemical and sensorial characteristics, in addition to the effect of climate, soil conditions and practices of hive handling and management (ESTEVINHO et al., 2016; SOUSA et al., 2016; ARAÚJO et al., 2017; SHAMSUDIN et al., 2019). Geographical origin and in particular botanical composition of the honey may also interfere with the physicochemical properties and eventually the product quality (FERNANDEZ ET AL., 2017; YA'AKOB et al., 2019).

Honey from multiple species of stingless bee exhibit a great potential for human consumption and commercialization due to the higher content of polyphenolic compounds, flavonoids, and antioxidants, as compared with Apis mellifera honey (RODRÍGUEZ-MALAVER et al., 2009; OLIVEIRA et al., 2012; KHONGKWANMUEANG et al., 2020). In addition, bioactive, therapeutic, and medicinal effects of stingless bee honeys have been documented across different stingless bee species (WATANABE et al., 2014; BILUCA et al., 2016; RAO et al., 2016; YAACOB et al., 2017; AMIN et al., 2018; KHONGKWANMUEANG et al., 2020). Globally, there are more than 500 species of stingless bees, the majority of which are described from the Neotropical and Sub-Tropical region (CAMARGO \& PEDRO, 2007; MICHENER, 2013). RASMUSSEN \& DELGADO (2019) reported 69 different species of stingless bees from Loreto in Perú; although, as many as 140 different Peruvian species of stingless bees are known. This number includes many as of yet undescribed species.

There are a few studies on Melipona eburnea, which is the main species of stingless bee kept in the central and northern Peruvian Amazon (RASMUSSEN \& CASTILLO 2003; DELGADO et al., 2019). The aim of the current study was to assess the feasibility in terms of profitability and sustainable management of honey production from M. eburnea and related stingless bee species in Peru. The use of standard hives was evaluated, and honey samples were assessed for quantity, physicochemical properties, and microbiological characteristics, at two different maturation ages. We also compared the characteristics of M. eburnea honey with that of three other related species in the same genus (M. grandis, $M$. illota, and $M$. titania) which are often kept in close proximity to $M$. eburnea colonies in flooded agroforestry systems in Peru.

\section{MATERIALS AND METHODS}

\section{Study areas}

The study was conducted from January 2016 to May 2018 in "meliponarios" (a collection of stingless bee hives) established in three communities located in the buffer zone of the Pacaya-Samiria National Reserve (RNPS) in Loreto, Peru; in the community of Chingana $\left(-4.7190^{\circ},-73.5460^{\circ}\right)$ and Bagazán $\left(-4.7238^{\circ},-73.5327^{\circ}\right)$ both in the province of Requena; and in the community of San Francisco $\left(-4.4469^{\circ},-73.5149^{\circ}\right)$ in the province of Loreto. The nutrient-rich soils occur on a flat topography which is flooded for 4 to 5 months every year when river levels rise (KALLIOLA et al., 1993). The climate is characterized as tropical humid with two well-defined seasons: the lowering of river levels or summer season, which coincides with the season of least precipitation (May to October), and the rising of river levels or winter season, which coincides with the season of greatest precipitation (November to April). Climatic conditions include an average annual temperature of $25.9^{\circ} \mathrm{C} \pm 2.0$, high relative humidity (90\%), and an annual rainfall of $2750 \mathrm{~mm}$ (KVIST \& NEBEL, 2001). In these flooded agroforestry systems, a great diversity of crops are cultivated. Together with the surrounding natural vegetation, 
they constitute an abundant source of floral resources for bees throughout the year.

\section{Management}

For the present study, vertical rational boxes were used, following the design by VENTURIERI et al. (2018), but modified according to the size of the honey and pollen pots of Peruvian M. eburnea. The rational boxes are composed of five pieces: trash, nest, top-nest, two honey sections, and lid (Figure 1 and Figure 2). For the present study, the height of the honey sections were reduced to $4.5 \mathrm{~cm}$, in keeping with the known maximum height of honey and pollen storage pots in $M$. eburnea (DELGADO et al., 2019). With this modification, the storage pots are forced into a single layer from which the honey may be harvested by opening the operculum of the pots and avoiding further destruction of the pots. Six colonies of $M$. eburnea originally kept in traditional log hives were transferred to an equal number of rational hive boxes. After a minimum of 2 months to allow the colonies to become habituated to the rational boxes, the six colonies were divided twice over a period of 10 months so that 24 colonies were obtained for the study. No artificial feeding was added in the period. In the rational hive boxes, the total volume of honey produced and its physicochemical and microbiological characteristics were assessed after 90 (T1) and 180 days (T2), following the first honey harvest. Colony growth was evaluated at 90 and 180 days after the nest installation or nest division. To evaluate colony growth and to generate new hives for the study, strong nests were selected at the outset which had $8-11$ brood combs, including at least three yellowish combs, an indication that juvenile individuals were close to emergence. When larvae are still growing, combs are dark brown in color. From these colonies, four new combs with adult bees were each transferred to new rational hive boxes (daughter colony), with the rest of the brood remaining in the mother colony. While it was not possible to assess the population size of each colony, the colonies were of a comparable size as the same number and size of brood combs were used to start each colony.

\section{Physicochemical and microbiological characterization of honey}

The physicochemical and microbiological characterization of honey was conducted after 90 days of colony growth for M. eburnea, M. grandis, and $M$. illota. Unfortunately, samples could only be taken at both 90 and 180 days for M. eburnea. Honey from the scarce $M$. titania was extracted from a natural log hive of unknown age and included here for reference only. Honey was extracted using a $100-\mathrm{mL}$ hypodermic

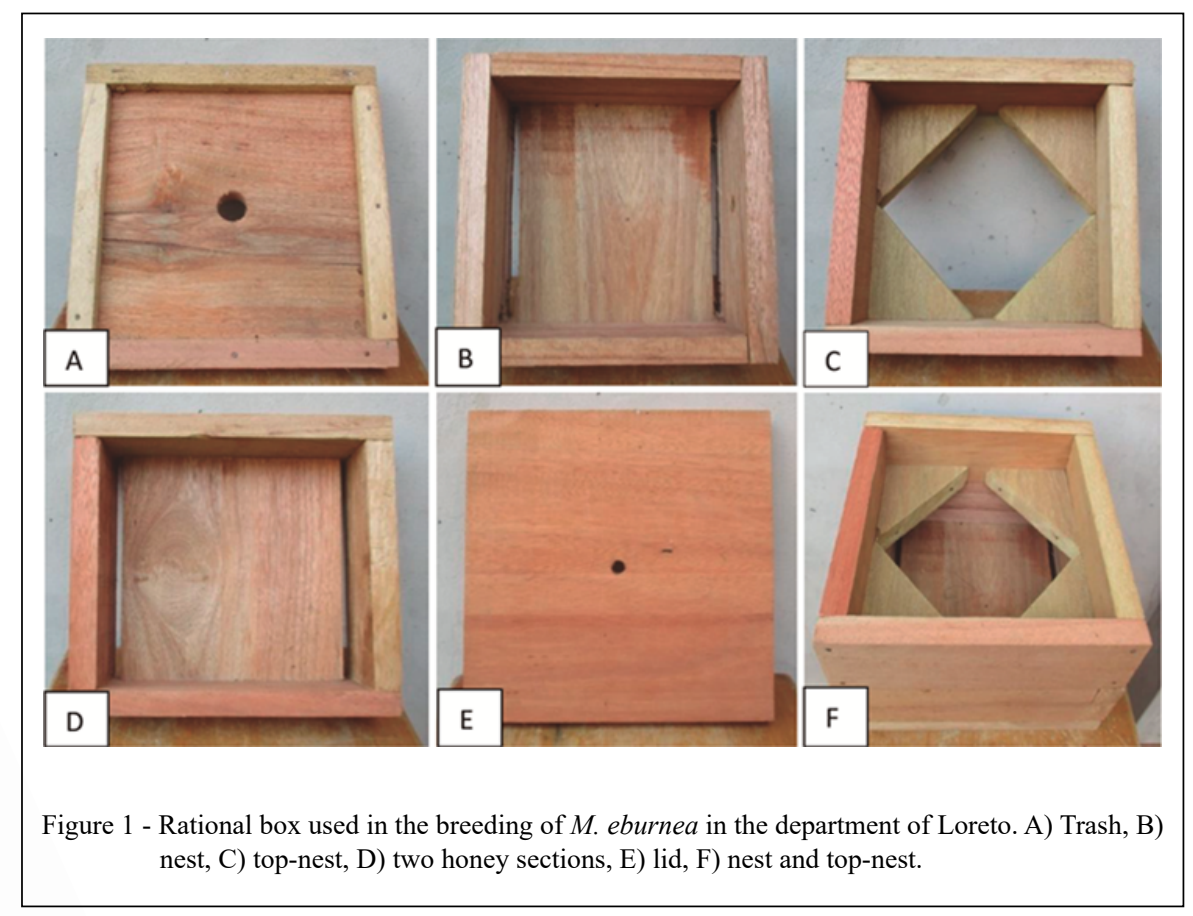

Ciência Rural, v.50, n.12, 2020. 


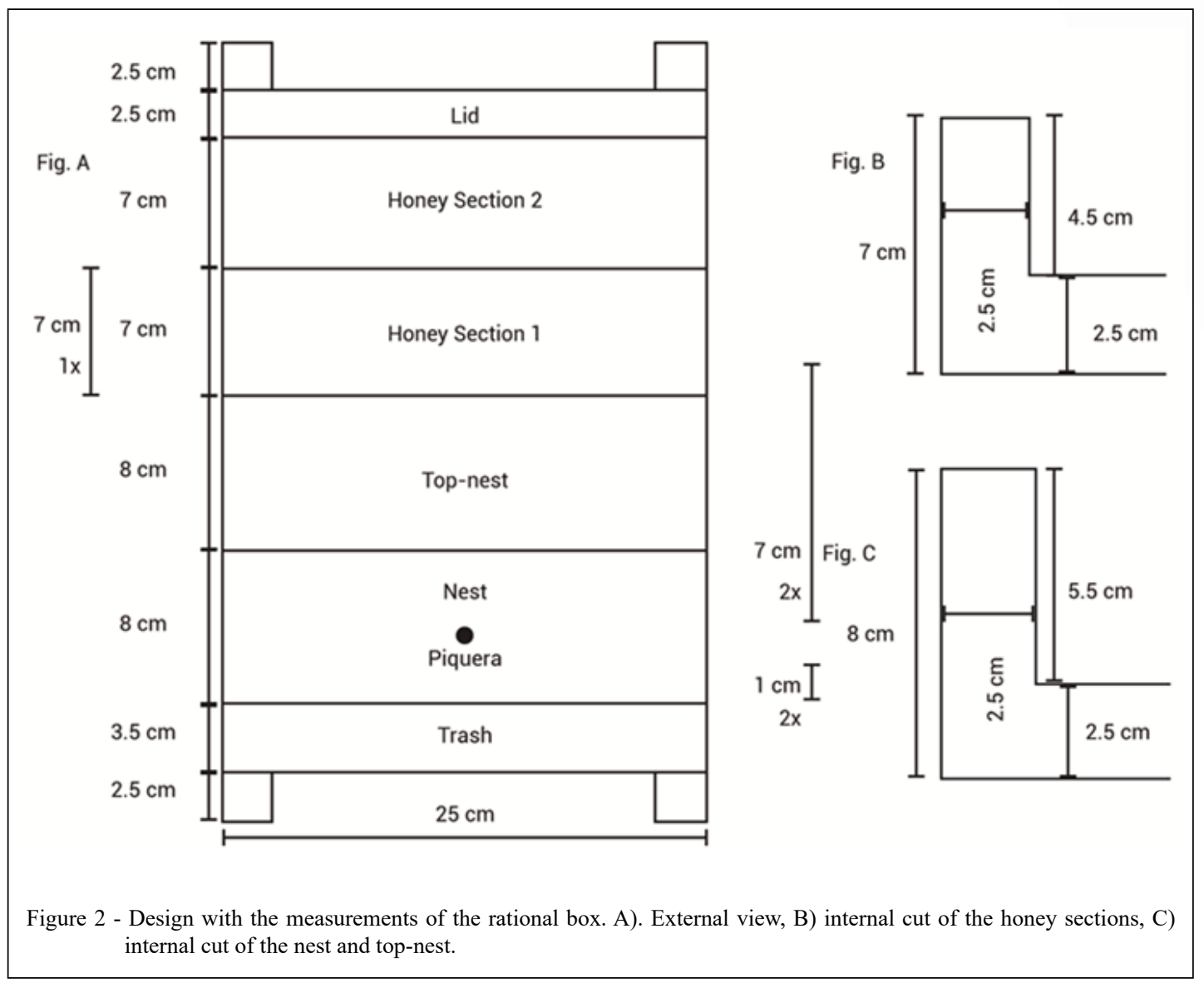

syringe and then placed in plastic bottles disinfected with a sodium hypochlorite solution. Samples were transported to the laboratory to measure the total amount of honey to the nearest hundred in a graduated cylinder with a maximum volume of $1500 \mathrm{~mL}$. Honey samples were analyzed in the laboratories of Servicio de Certificaciónes del Perú S.A. (CERPER), Lima, Peru. The physicochemical variables evaluated and protocols followed were as follows: moisture (NTP 209.171:1999, 2014; g/100 g honey), ash (NTP 209.175:1999, 2014; g/100 g honey), pH (AOAC, 2016; units at $25^{\circ} \mathrm{C}$ ), 5-hydroxymethylfurfural using the spectrophotometric method (NTP 209.176:1999, 2014; mg HMF/100 g honey), diastase activity (NTP 209.177:1999, 2014; 1\% starch solution/g honey/h, at $40{ }^{\circ} \mathrm{C}$ ), and total and individual sugars using the HPLC method (AACC, 2010; g/100 $\mathrm{g}$ honey, fructose, glucose, sucrose (saccharose), maltose, or lactose). The microbiological variables were assessed by the most probable number (MPN) (INTERNATIONAL COMMISSION ON MICROBIOLOGICAL SPECIFICATIONS FOR
FOODS (ICMSF), 1983). Statistical tests were conducted using the program BioEstat 5.0 (Sociedade Civil Mamirauá, Amazonas, Brazil).

\section{RESULTS AND DISCUSSION}

\section{Management}

Melipona eburnea, locally known as "ronsapilla," "ronsapilla amarilla," "pacuchita," "boca de sapo," or "la legitima," was the most commonly encountered species of stingless bee kept in traditional tree trunk hives or boxes (Figure 3A, figure $3 \mathrm{~B}$ ). Following the habituation period of bees to the rational hive boxes, the production of honey during both time treatments varied from 900 to 1400 $\mathrm{mL} /$ colony/3 months; the production after 90 days was on average $1200 \mathrm{~mL}(\mathrm{SD}=144 ; \mathrm{N}=12)$, and after 180 days, it had increased slightly to an average of $1300 \mathrm{~mL}(\mathrm{SD}=113 ; \mathrm{N}=11)$. The difference in honey volume between the two time points was not significant $(\mathrm{P}=0.166$, Mann-Whitney $\mathrm{U}$ test). The production of stingless bee honey in traditional 


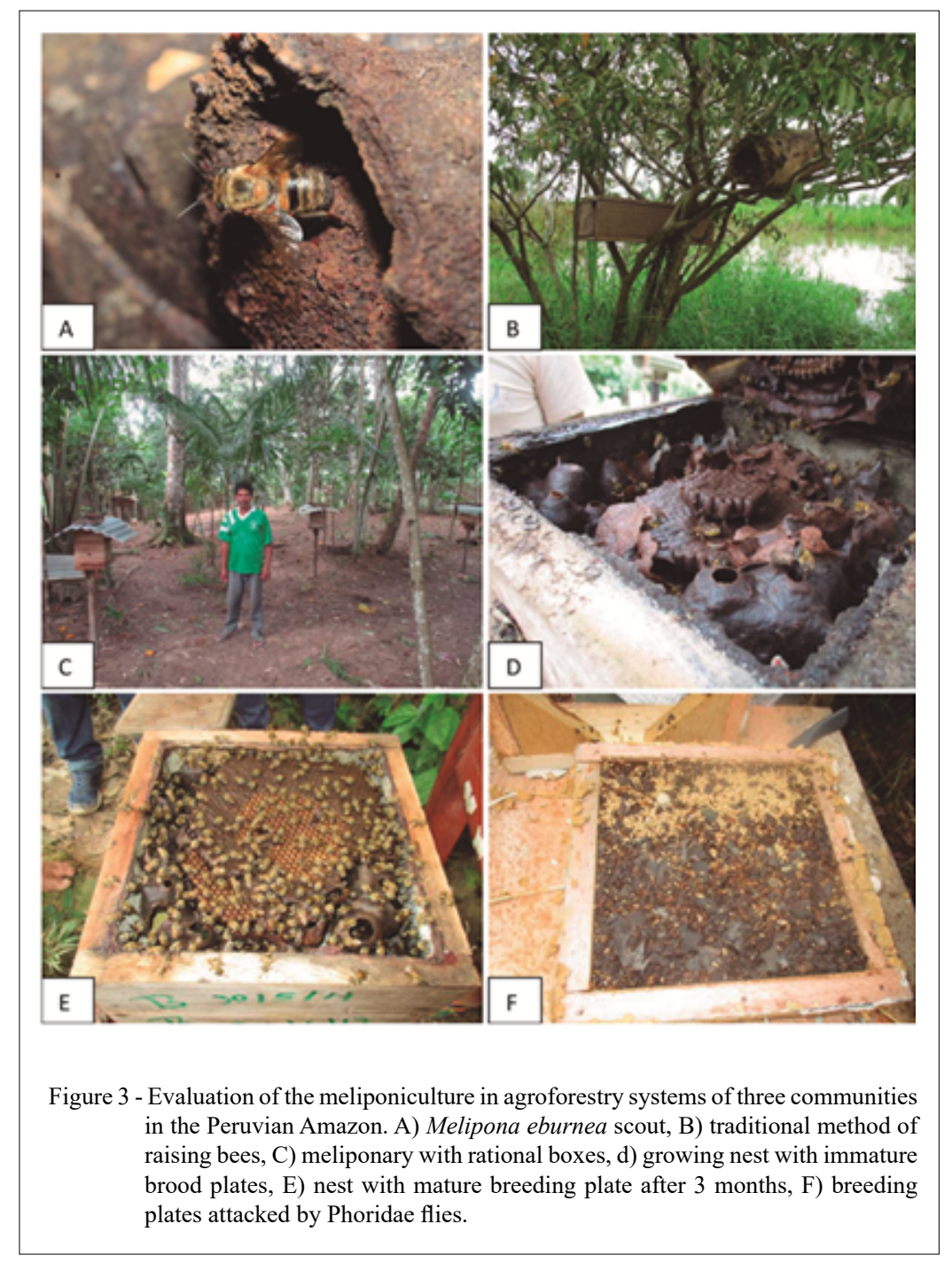

logs or boxes is on average $250-1800 \mathrm{~mL}$ every 8-16 months. However, this production may be significantly increased if modern rational boxes are used. Production can reach up to $4800 \mathrm{~mL} / 12$ months (extrapolation of $1200 \mathrm{~mL} / 3$ months * 4 ) or four times more than the production in traditional logs. After 90 days following colony splitting, the daughter colonies produced $8-11$ brood combs, with diameters up to $17 \mathrm{~cm}$ in the last three combs; the upper part of the cells was brown to yellow in color $(\mathrm{N}=22)$ (Figure $3 \mathrm{C}$, figure $3 \mathrm{D}$ and figure $3 \mathrm{E}$ ). In the original mother colonies, colony sizes recovered at a faster rate, due in part to the greater number of adult individuals and the brood combs that remained in place.

While evaluations were carried out during the peak flowering season, flowering in these natural and cultivated flooded systems occurs throughout the year. Rates of honey production that we quantified are in line with previous studies on a related species: Melipona fasciculata in the Pará State produced 3000-4000 mL/colony/year (MAGALHÃES \& VENTURIERI, 2010). The postharvest stress suffered by the colony stimulates the bees to collect more honey in the initial months following the extraction (GOSTINSKI et al., 2017). Similar behavior was observed in the present study where honey gathering increased after the first batch of honey had been removed. This is in contrast to the initial colony transfer to a rational hive, when the bees must first produce wax and collect mud and resins to protect and restore the colony before they can gather resources. The destruction of honey

Ciência Rural, v.50, n.12, 2020. 
and pollen pots during the honey harvest is one of the main factors in the low production in traditional meliponiculture systems.

$\begin{aligned} & \text { Physicochemical and microbiological } \\ & \text { characterization of honey } \\ & \text { During this study, } 13 \text { samples of honey }\end{aligned}$ were collected from stingless bees kept in rational hives, namely, six samples of M. eburnea, four of $M$. grandis, and three of M. illota. In addition, two honey samples of $M$. titania were collected from $\log$ hives. Three of the M. eburnea honey samples were taken after 90 days, and three, from different colonies, were taken after 180 days. Physicochemical and microbiological characteristics of honey were similar for the four species and within each species at the two time points; Moisture $30.9(\mathrm{~g} / 100 \mathrm{~g}$ honey), Ash 0.1 (g/100 g honey), $\mathrm{pH} 3.2$ (at $25^{\circ} \mathrm{C}$ ), 5-hydroxymethylfurfural 6.1 (mg HMF/100 g honey), Diastase activity 11.3 (1\% starch solution/g honey/h, at $\left.40{ }^{\circ} \mathrm{C}\right)$, and Total sugars $53.3(\mathrm{~g} / 100 \mathrm{~g}$ honey) (Table 1). When the variable moisture and total sugars were compared among the species, no significant differences were observed for moisture $(P=0.72$, ANOVA test) or total sugars ( $\mathrm{P}=0.57$, ANOVA test $)$. The characteristics of $M$. eburnea honey were similar at 90 and 180 days, with no significant differences for moisture $(\mathrm{P}=0.46$, $\mathrm{t}$-test $)$ or total sugars $(\mathrm{P}=0.43$, t-test) (Table 2). The microbiological analysis of honey for the different species and for $M$. eburnea honey harvested at 90 and 180 days resulted in values $<0.3 \mathrm{NMP} / \mathrm{g}$. This suggested that M. eburnea honey can be harvested 90 days after each harvest, as the physicochemical and microbiological characteristics are similar to mature honeys greater than 180 days. When the quality parameters of stingless bee honey were compared with those for the western honey bee Apis mellifera in the Codex Alimentarius, the moisture content of stingless bee honey (30.91\%, $\mathrm{SD}=3.26$ ) was above the maximum allowed for A. mellifera $(<20 \%)$, whereas total sugars $(53.33$ $\mathrm{g} / 100 \mathrm{~g}$ honey, $\mathrm{SD}=5.52$ ) were below the minimum required for honey from $A$. mellifera $(>60 \mathrm{~g} / 100 \mathrm{~g}$ honey). Studies conducted on honeys from different species of stingless bees in Peru (RODRÍGUEZMALAVER et al., 2009) and elsewhere (BILUCA et al., 2016; GOMES et al., 2017; LEMOS et al., 2017; FERNANDES et al., 2018) exhibited similar characteristics, which emphasizes the necessity to establish a technical standard specific to honey from stingless bees. Moisture is one of the parameters important for quality as it is related to the fermentation of honey. Honeys that have $>20 \%$ moisture are much more prone to fermentation. However, stingless bee honeys in the present study were extracted under clean conditions and stored at ambient temperature for nearly 4 years without fermentation. The high antibiotic content present in the honey of stingless bees may be one of the reasons why rapid fermentation is avoided, as long as contaminations during collection are kept to a minimum. Laboratory tests of stingless bee honey have, for example, revealed that stingless bee honey is a more powerful inhibitor of bacteria than honey from $A$. mellifera bees

Table 1 - Physicochemical characterization of honey from Melipona eburnea, M. illota, and M. grandis. Differences between these honeys were not significantly different $(\mathrm{P}=0.72$, ANOVA test $)$.

\begin{tabular}{|c|c|c|c|c|c|}
\hline Species/Tests & M. eburnea $\mathrm{n}=6$ & M. grandis $\mathrm{n}=4$ & M. illota $\mathrm{n}=3$ & M. titania $\mathrm{n}=2$ & Total X/ SD \\
\hline Moisture (g/100 g honey) & 31.76 & 30.85 & 28.9 & 31.3 & $30.9 / 3.2$ \\
\hline Ash (g/100 g honey) & 0.06 & 0.04 & 0.04 & 0.06 & $0.1 / 0.0$ \\
\hline $\mathrm{pH}\left(\right.$ at $\left.25^{\circ} \mathrm{C}\right)$ & 3.22 & 3.08 & 3.41 & 3.24 & $3.2 / 0.3$ \\
\hline $\begin{array}{l}\text { 5-hydroxymethylfurfural (mg HMF/100 } \\
\text { g honey) }\end{array}$ & 12.04 & 2.4 & 1.81 & 1.68 & $6.1 / 15.4$ \\
\hline $\begin{array}{l}\text { Diastase activity ( } 1 \% \text { starch solution } / \mathrm{g} \\
\left.\text { honey/h, at } 40^{\circ} \mathrm{C}\right)\end{array}$ & 9.8 & 10.12 & 15.5 & - & $11.3 / 6.1$ \\
\hline Total sugars (g/100 g honey) & 55.8 & 50.71 & 55.96 & 55.51 & $53.3 / 5.5$ \\
\hline Glucose (g/100 g honey) & 26.61 & 24.26 & 26.97 & 27.33 & $25.5 / 3.1$ \\
\hline Fructose (g/100 g honey) & 28.98 & 26.01 & 28.99 & 28.18 & $27.4 / 3.2$ \\
\hline Saccharose (g/100 g honey) & $<7$ & $<7$ & $<7$ & $<7$ & $<.7$ \\
\hline Lactose (g/100 g honey) & $<7$ & $<7$ & $<7$ & $<7$ & $<7$ \\
\hline Maltose (g/100 g honey) & $<7$ & $<7$ & $<7$ & $<7$ & $<7$ \\
\hline Coliforms MPN & $<3$ & $<3$ & $<3$ & $<3$ & $<3$ \\
\hline Organisms of fecal origin & $<3$ & $<3$ & $<3$ & $<3$ & $<3$ \\
\hline
\end{tabular}


Table 2 - Physicochemical characterization of Melipona eburnea honey at 90 and 180 days after the last extraction. Differences between these time points were not significant $(\mathrm{P}=0.46$, t-test $)$.

\begin{tabular}{|c|c|c|}
\hline Tests & 180 days $(\mathrm{n}=3)$ & 90 days $(n=3)$ \\
\hline Moisture (g/100 g honey) & 31.6 & 31.9 \\
\hline Ash (g/100 g honey) & 0.08 & 0.04 \\
\hline $\mathrm{pH}\left(\right.$ at $\left.25^{\circ} \mathrm{C}\right)$ & 3.32 & 3.08 \\
\hline 5-hydroxymethylfurfural (mg HMF/100 g honey) & 20 & 0.11 \\
\hline Diastase activity $\left(1 \%\right.$ starch solution $/ \mathrm{g}$ honey/h, at $\left.40^{\circ} \mathrm{C}\right)$ & 6.83 & 14.21 \\
\hline Total sugars (g/100 g honey) & 55.96 & 55.55 \\
\hline Glucose (g/100 g honey) & 26.27 & 27.14 \\
\hline Fructose (g/100 g honey) & 29.36 & 28.41 \\
\hline Saccharose (g/100 g honey) & $<0.7$ & $<0.7$ \\
\hline Lactose (g/100 g honey) & $<0.7$ & $<0.7$ \\
\hline Maltose (g/100 g honey) & $<0.7$ & $<0.7$ \\
\hline
\end{tabular}

(BRADBEAR, 2009; RODRÍGUEZ-MALAVER et al., 2009; YAACOB, et al., 2017; AMIN et al., 2018; KHONGKWANMUEANG et al., 2020).

\section{Opportunities for marketing and market}

The wide uses of stingless honey in traditional medicine, the increasing scientific evidence of the presence of chemical compounds, and their curative effects for several diseases are factors that favor the local and regional growth of the market for this product. Traditionally, the commercialization of honey is carried out on the sidewalks of local markets and by street vendors in the big cities of the Peruvian Amazon. A $600-\mathrm{mL}$ bottle of stingless bee honey or Apis mellifera honey extracted from the rainforest is sold for between 3.00 and 4.50 USD ( 1 USD $=3.34$ PEN). This honey is often offered with abundant solid residues of wood, geopropolis (soil-enriched resin), and dead bees and sometimes adulterated with foreign products that limit its commercialization. Buyers are; therefore, willing to pay better prices for honeys directly from the meliponaries that guarantee an unaltered purity. Communities that are adopting production practices in rational hive boxes can properly market their product with basic quality information in a $600-\mathrm{mL}$ bottle for 15 USD. In the community of San Francisco on the Marañón River, stingless beekeeping in hives is now incorporated into their tourist activities. Tourist companies that for many years have visited the community for the beautiful crafts produced using the Astrocaryum chambira palm fiber now also include the "meliponario" as part of the tourist route within the community. Commercial production risks include lack of market and problems with proper authentication of sustainably produced honey, in addition to colony pests. During the experiment, five colonies were lost due to attacks by the vinegar fly (Pseudohypocera kerteszi (Enderlein) (Diptera: Phoridae) (Figure 3F) and the fire ant Solenopsis spp. (Hymenoptera: Formicidae).

\section{CONCLUSION}

Meliponiculture is an activity that holds great potential for development. The rapid adaptation of colonies to rational boxes and the favorable physicochemical and microbiological results reported in this study demonstrate that this activity has the potential to be both profitable and sustainable. We revealed that honey production in rational hives can quadruple annual honey production when compared with traditional techniques. Three month old honey has similar physicochemical and microbiological characteristics to honey older than 6 months and should thus be ready for harvesting already after three months. It should be noted that the market value of honey continues to rise substantially. Honey from stingless bees has the added advantages of medicinal properties and a sustainable production. However, pests are an important adverse factor that should be considered in meliponiculture. Serious losses can be caused by the vinegar fly (Diptera: Phoridae, Pseudohypocera kerteszi) and different ant species (Hymenoptera: Formicidae). The main quality parameters for stingless bee honey differ from those specified in the Codex Alimentarius Standard for honey. Therefore, it is necessary to establish regulations specific to stingless bee honey in Peru.

Ciência Rural, v.50, n.12, 2020. 


\section{DECLARATION OF CONFLICT OF INTERESTS}

The authors declare no conflict of interest. The research was funded by the Concejo Nacional de Ciencia y Tecnología-CONCYTEC-Cienciactiva.

\section{AUTHOR'S CONTRIBUTIONS}

All authors contributed equally to the conception, writing, and revisions of the manuscript.

\section{ACKNOWLEDGMENTS}

This contribution is part of a larger project developed by the Biodiversity Program of Instituto de Investigaciones de la Amazonía Peruana, financed by Concejo Nacional de Ciencia y Tecnología in Peru. English language was improved by CESDAB

\section{BIOETHICS AND BIOSSECURITY COMMITTEE APPROVAL DECLARATION}

We authors of the article entitled "Management practices and honey characteristics of Melipona eburnea Friese in the Peruvian Amazon" declared, for all due purposes, the project that gave rise to the present data of the same has not been submitted for evaluation to the Ethics Committee of the Aarhus University or the Research Institute of the Peruvian Amazon, but we are aware of the contents of Resolution No. 466, of the Brazilian National Health Council "http://conselho.saude.gov.br/resolucoes/2012/ Reso466.pdf" if it involves human and of the content of the Brazilian resolutions of the National Council for Control of Animal Experimentation - CONCEA "http://www.mct.gov.br/ index.php/content/view/310553.html" if it involves animals. Thus, the authors assume full responsibility for the presented data and are available for possible questions, should they be required by the competent authorities.

\section{REFERENCES}

AACC. Approved Methods of Analysis of the American Association of Cereal Chemistry, 11th ed. St. Paul, MN: AACC International. 2010.

ALVES, R. R. N.; H. N. ALVES. The faunal drugstore: Animalbased remedies used in traditional medicines in Latin America. Journal of Ethnobiology and Ethnomedicine, v.7, n.9, p.2-43. 2011. Available from: $<$ https://www.doi.org/10.1186/1746-42697-9>. Accessed: Jul. 30, 2020. doi: 10.1186/1746-4269-7-9.

AMIN, F. A. Z., et al., Therapeutic properties of stingless Bee Honey in Comparison with European Bee Honey. Advances in Pharmacological Sciences, v.12, p.1-12. 2018. Available from: $<$ https://doi.org/10.1155/2018/6179596>. Accessed: Jul. 30, 2020. doi: $10.1155 / 2018 / 6179596$.

AOAC. Official method 981.12. pH of acidified foods. Official Methods of Analysis, 20th ed. Washington D.C.: AOAC International. 2016.

ARAÚJO, J. S., et al., Chemical composition and biological activities of mono-and heterofloral bee pollen of different geographical origins. International Journal of Molecular Sciences, v.18, n.5, p.921. 2017. Available from: <https://www. doi.org/10.3390/ijms18050921>. Accessed: Jul. 30, 2020. doi: 10.3390/ijms 18050921 .

BILUCA, F. C., et al., Physicochemical profiles, minerals and bioactive compounds of stingless bee honey (Meliponinae). Journal of Food Composition and Analysis, v.50, p.6169. 2016. Available from: <https://www.doi.org/10.1016/j. jfca.2016.05.007>. Accessed: Jul. 30, 2020. doi: 10.1016/j. jfca.2016.05.007.

BRADBEAR, N. Bees and their role in forest livelihoods. A guide to the services provided by bees and the sustainable harvesting, processing and marketing of their products. FAO. Rome, p.16. 2009

CAMARGO, J. M. F.; S. R. M. PEDRO. Meliponini. In: J. S. Moure, D. Urban, et al (Ed.). Catalogue of bees (Hymenoptera, Apoidea) in the Neotropical region. Curitiba (Paraná): Sociedade Brasileira de Entomologia, 2007. Meliponini, p.272-578.

CORTOPASSI-LAURINO, M., et al., Global meliponiculture: challenges and opportunities. Apidologie, v.37, n.2, p.275292. 2006. Available from: <https://www.doi.org/10.1051/ apido:2006027>. Accessed: Jul. 30, 2020. doi: 10.1051/ apido:2006027.

DELGADO, C., et al., Manual para criar abejas sin aguijón con énfasis en la "ronsapilla" Meliponea eburnea. Lima (Peru): IIAP. 2019. 48p. Available from: <http://repositorio.iiap.gob.pe/ bitstream/IIAP/397/1/Delgado_libro_2019b.pdf $>$. Accessed: Jul. 30, 2020.

EARDLEY, C. D.; P. KWAPONG. Taxonomy as a tool for conservation of Africa stingless bees and their honey. In: P. Vit, S. R. M. Pedro, et al (Ed.). Pot-Honey: A legacy of stingless bees. New York: Springer, 2013. Taxonomy as a tool for conservation of Africa stingless bees and their honey, p.261-268.

ESTEVINHO, L. M., et al., Characterization of Lavandula spp. honey using multivariate techniques. PLoS One, v.11, n.9, p.e0162206. 2016. Available from: < https://www.doi.org/10.1371/ journal.pone.0162206>. Accessed: Jul. 30, 2020. doi: 10.1371/ journal.pone.0162206

FERNANDES, R. T., et al., Microbiological and physicalchemical characteristics of honeys from the bee Melipona fasciculata produced in two regions of Brazil. Ciência Rural, v.48, n.5, p.e20180025. 2018. Available from: <https://www.doi. org/10.1590/0103-8478cr20180025>. Accessed: Jul. 30, 2020. doi: $10.1590 / 0103-8478 \mathrm{cr} 20180025$.

GARIBALDI, L. A., et al., Mutually beneficial pollinator diversity and crop yield outcomes in small and large farms. Science. v.351, n.6271, p.388-391. 2016. Available from: <https://www. doi.org/10.1126/science.aac7287>. Accessed: Jul. 30, 2020. doi: 10.1126/science.aac7287.

GIANNINI, T. C., et al., Crop pollinators in Brazil: a review of reported interactions. Apidologie, v.46, n.2, p.209-223. 2015. Available from: $<$ https://www.doi.org/10.1007/s13592-014-0316-z>. Accessed: Jul. 30, 2020. doi: 10.1007/s13592-014-0316-z.

GOMES, V. V., et al., Avaliação da Qualidade do Mel Comercializado no Oeste do Pará, Brasil. Revista Virtual de 
Química, v.9, n.2, p.815-826. 2017. Available from: $<$ https://www. doi.org/10.21577/1984-6835.20170050>. Accessed: Jul. 30, 2020. doi: $10.21577 / 1984-6835.20170050$.

GOSTINSKI, L. F., et al., Effect of honey harvest on the activities of Melipona (Melikerria) fasciculata Smith, 1854 workers. Journal of Apicultural Research, v.56, n.4, p.319-327. 2017. Available from: <https://www.doi.org/10.1080/00218839.2017.1329795> . Accessed: Jul. 30, 2020. doi: 10.1080/00218839.2017.1329795.

INTERNATIONAL COMMISSION ON MICROBIOLOGICAL SPECIFICATIONS FOR FOODS (ICMSF). Microorganismos de los Alimentos 2. Métodos de Muestreo para Análisis Microbiológico: Principios y Aplicaciones Específicas. Saragoza: Editorial Acribia, S.A. 1983

JAFFÉ R, et al., Bees for Development: Brazilian Survey Reveals How to Optimize Stingless Beekeeping. PLoS ONE, 10(3): e0121157. 2015. Available from: $<$ https://doi.org/10.1371/journal pone.0121157>. Accessed: Jul. 30, 2020. doi: 10.1371/journal. pone. 0121157

KAlliola, R., et al., Eds. Amazonia peruana. Vegetación húmeda tropical en el llano subandino. Turku: Proyecto Amazonia, Universidad de Turku, p.265. 1993.

KERR, E., et al., Aspectos pouco mencionados da biodiversidade amazônica. Parcerias Estratégicas, v.6, n.12, p.20-41. 2001 Available from: <http://seer.cgee.org.br/index.php/parcerias estrategicas/article/view/183>. Accessed: Jul. 30, 2020.

KHONGKWANMUEANG, A., et al., Physicochemical Profiles, Antioxidant and Antibacterial Capacity of Honey from Stingless Bee Tetragonula laeviceps Species Complex. E3S Web of Conferences 141, e03007. 2020. Available from: <https://doi. org/10.1051/e3sconf/202014103007>. Accessed: Jul. 30, 2020. doi: $10.1051 / \mathrm{e} 3$ sconf/202014103007.

KOFFLER, S., et al., Temporal variation in honey production by the stingless bee Melipona subnitida (Hymenoptera: Apidae): longterm management reveals its potential as a commercial species in Northeastern Brazil. Journal of Economic Entomology, v.108, n.3, p.858-867. 2015. Available from: <https://pubmed.ncbi.nlm.nih. gov/26470204/>. Accessed: Jul. 30, 2020. doi: 10.1093/jee/tov055.

KVIST, L. P.; G. NEBEL. A review of Peruvian flood plain forests: ecosystems, inhabitants and resource use. Forest Ecology and Management, v.150, n.1-2, p.3-26. 2001. Available from: $<$ https:// www.doi.org/10.1016/S0378-1127(00)00679-4>. Accessed: Jul. 30, 2020. doi: 10.1016/S0378-1127(00)00679-4.

LAGE, L. G. A., et al., Honey physicochemical properties of three species of the brazilian Melipona. Anais da Academia Brasileira de Ciências, v.84, n.3, p.605-608. 2012. Available from: < https:// doi.org/10.1590/S0001-37652012005000051>. Accessed: Jul. 30, 2020. doi: 10.1590/S0001-37652012005000051.

LEMOS, M. S., et al., Evaluation of the physicochemical parameters and inorganic constituents of honeys from the Amazon region. Journal of Apicultural Research, v.57, n.1, p.135-144. 2017. Available from: <https://www.doi.org/10.1 080/00218839.2017.1338120>. Accessed: Jul. 30, 2020. doi: 10.1080/00218839.2017.1338120.

MAGAlHÃES, T. L. D.; G. A. VENTURIERI. Aspectos Econômicos da Criação de Abelhas Indígenas Sem Ferrão
(Apidae: Meliponini) no Nordeste Paraense. Belém, PA: Embrapa Amazônia Orienta. 2010. 36p.

MICHENER, C. D. The bees of the world, second edition. Baltimore: Johns Hopkins University Press. 2007. xvi+953p.

MICHENER, C. D. The Meliponini. In: P. Vit, S. R. M. Pedro, et al (Ed.). Pot-Honey: A legacy of stingless bees. New York: Springer, 2013. The Meliponini, p.3-17.

NTP 209.171:1999. Miel. Determinación de humedad. 2a. ed. Lima: Normas Técnicas Peruanas. 2014. 3p.

NTP 209.175:1999. Miel. Determinación del contenido de sustancias minerales (cenizas). 2a. ed. Lima: Normas Técnicas Peruanas. 2014. 2p.

NTP209.176:1999. Miel. Determinación dehidroximetilfurfural. Método espectrofotométrico. 2a. ed. Lima: Normas Técnicas Peruanas. 2014. 3p.

NTP 209.177:1999. Miel. Determinación de la actividad de la diastasa. 2a. ed. Lima: Normas Técnicas Peruanas. 2014. 6p.

OLIVEIRA, P. S., et al., Ácidos fenólicos, flavonoides e atividade antioxidante em méis de Melipona fasciculata, M. flavolineata (Apidae, Meliponini) e Apis mellifera (Apidae, Apini) da Amazônia. Química Nova, v.35, n.9, p.1728-1732. 2012. Available from: $<$ https://doi.org/10.1590/S0100-40422012000900005>. Accessed: Jul. 30, 2020. doi: 10.1590/S0100-40422012000900005.

QUEZADA-E., J. J. G., et al., Economic and Cultural Values of Stinglees Bees (Hymenoptera: Meliponini) among Ethnic Groups of Tropical America. Sociobiology, v.65, n.4, p.534-557. 2018. Available from: <https://doi.org/10.1312/sociobiology.v65. i43447>. Accessed: Jul. 30, 2020. doi: 10.13102/sociobiology. v65i4.3447.

RAO, P. V., et al., Biological and therapeutic effects of honey produced by honey bees and stingless bees: a comparative review. Revista Brasileira de Farmacognosia, v.26, n.5, p.657-664. 2016. Available from: <https://doi.org/10.1016/j.bjp.2016.01.012>. Accessed: Jul. 30, 2020. doi: 10.1016/j.bjp.2016.01.012.

RASMUSSEN, C.; P. S. CASTILLO. Estudio preliminar de la Meliponicultura o apicultura silvestre en el Perú (Hymenoptera: Apidae, Meliponini). Revista Peruana de Entomología, v.43, p.159-164. 2003. Available from: <https://museohn.unmsm. edu.pe/docs/pub_ento/Rasmussen2003_Perumelipocultura.pdf $>$. Accessed: Jul. 30, 2020

RASMUSSEN, C.; C. DELGADO. Abejas sin aguijón (Apidae: Meliponini) en Loreto, Perú. Lima (Perú): IIAP. 2019. 70p. Available from: <http://repositorio.iiap.org.pe/bitstream/ IIAP/396/1/Delgado_libro_2019a.pdf>. Accessed: Jul. 30, 2020.

RODRÍGUEZ-MALAVER, A. J., et al., Properties of honey from ten species of peruvian stingless bees. Natural Product Communications, v.4, n.9, p.1221-1226. 2009. Available from: <https://www.doi.org/10.1177/1934578X0900400913>. Accessed: Jul. 30, 2020. doi: 10.1177/1934578X0900400913.

SHAMSUDIN, S., et al., Influence of origins and bee species on physicochemical, antioxidant properties and botanical discrimination of stingless bee honey. International Journal of Food Properties, v.22, n.1, p.239-264, 2019. Available 
from: $\quad<$ https://www.doi.org/10.1080/10942912.2019.1576730> . Accessed: Jul. 30, 2020. doi: 10.1080/10942912.2019.1576730.

SOUSA, J. M. B. et al., Sugar profile, physicochemical and sensory aspects of monofloral honeys produced by different stingless bee species in Brazilian semi-arid region. LWT - Food Science and Technology, v.65, p.645-651. 2016. Available from: $<$ https://www. doi.org/10.1016/j.lwt.2015.08.058> . Accessed: Jul. 30, 2020. doi: 10.1016/j.lwt.2015.08.058.

VENTURIERI, G. C., et al., Honey production of the "uruçucinzenta" stingless bee (Melipona fasciculata) after offering cerumen in natural form or as artificially made pots. Journal of Apicultural Research. v.57, n.1, p.129-134. 2018. Available from: <https://www.doi.org/10.1080/00218839.2017.1339520> . Accessed: Jul. 30, 2020. doi: 10.1080/00218839.2017.1339520.

VIT, P. Modificaciones comentadas de la norma Miel de Abejas, hacia la norma Miel de Venezuela: Inclusión de miel de pote y exclusión de mieles falsas. In: P. Vit e D. W. Roubik (Ed.). Stingless
Bees Process Honey and Pollen in Cerumen Pots. Mérida, Venezuela: Facultad de Farmacia y Bioanálisis, Universidad de Los Andes, 2013.

WATANABE, K. et al., Anti-influenza viral effects of honey in vitro: potent high activity of manuka honey. Archives of Medical Research, v.45, n.5, p.359-365. 2014. Available from: <https:// www.doi.org/10.1016/j.arcmed.2014.05.006>. Accessed: Jul. 30, 2020. doi: 10.1016/j.arcmed.2014.05.006.

YA'AKOB, A., et al., Evaluation of Physicochemical Properties of Trigona sp. Stingless Bee Honey from Various Districts of Johor. Jurnal Kejuruteraan, v.2, n.1, p.59-67. 2019. Available from: $<$ https://doi.org/10.17576/jkukm-2019-si2(1)-08>. Accessed: Jul. 30, 2020. doi: 10.17576/jkukm-2019-si2(1)-08.

YAACOB, M., et al., Stingless bee honey and its potential value: a systematic review. Food Research, v.2, n.2, p.124-133. 2017. Available from: $<$ https://www.doi.org/10.26656/fr.2017.2(2).212>. Accessed: Jul. 30, 2020. doi: 10.26656/fr.2017.2(2).212. 